\title{
EFFECTS OF EROSION AND DEPOSITION ON PARTICLE SIZE DISTRIBUTION OF DEPOSITED FARMLAND SOILS ON THE CHINESE LOESS PLATEAU ${ }^{(1)}$
}

\author{
Pei Zhao ${ }^{(2)}$, Ming An Shao ${ }^{(3)}$, Wail Omran $^{(4)}$ \& Abdel-monem Mohamed Amer ${ }^{(5)}$
}

\begin{abstract}
Particle size distribution (PSD) in the soil profile is strongly related to erosion, deposition, and physical and chemical processes. Water cycling and plant growth are also affected by PSD. Material sedimented upstream of the dam constructions formed large areas of deposited farmland (DF) soils on the Chinese Loess Plateau (CLP), which has been the site of the most severe soil erosion in the world. Two DFs without tillage on the CLP were chosen to study the combined effect of erosion and check dams on PSD. Eighty-eight layers (each $10 \mathrm{~cm}$ thick) of filled deposited farmland (FDF) soils and 22 layers of silting deposited farmland (SDF) soils of each studied soil profile were collected and 932 soil samples were investigated using laser granulometry. The particle sizes were stratified in both DFs based on soil properties and erosion resistance. The obtained results of clay and silt fractions showed similar horizontal distribution, indicating parallel characteristics of erosion and deposition processes. Fine sand represented the largest fraction, suggesting the preferential detachment of this fraction. The most erodible range of particle sizes was $0.25-0.5 \mathrm{~mm}$, followed by $0.2-0.25 \mathrm{~mm}$ in the studied soil profiles. The correlation between particle size and soil water contents tended to increase with increasing water contents in FDF. Due to the abundant shallow groundwater, the relationship between particle size and soil water content in SDF was lost. Further studies on PSD in the DF area are needed to enhance the conservation management of soil and water resources in this region.
\end{abstract}

Index terms: soil texture, stratification, soil erodibility, dam construction, soil conservation.

\footnotetext{
(1) Received for publication in March 31, 2011 and approved in August 17, 2011.

(2) Key Laboratory of Mountain Surface Processes and Ecological Regulation, Institute of Mountain Hazards and Environment, CAS, Chengdu, China

${ }^{(3)}$ Institute of Geographic Sciences and Natural Resources Research, CAS, Beijing, China. E-mail: shaoma@igsnrr.ac.cn

(4) Temporary address: Department of Biology, Faculty of Science, Taif University, Saudi Arabia Permanent address: Department of Soil Science, Faculty of Agriculture, Menoufia University, Egypt. E-mail: womran@yahoo.com

(5) Department of Soil Science, Faculty of Agriculture, Menoufia University, Egypt. E-mail: amer_abdel@hotmail.com
} 


\title{
RESUMO: EFEITODA EROSÃO E DA DEPOSIÇÃO SOBRE ADISTRIBUIÇÃO DO TAMANHO DE PARTÍCULAS DE SOLOS DE DEPÓSITOS DE ÁREAS AGRÍCOLAS NO "LOESS PLATEAU” NA CHINA
}

\begin{abstract}
A distribuição do tamanho das partículas do solo (PSD) está fortemente relacionada à sua erosão, deposição e aos processos físicos e químicos ocorridos no perfil do solo. A ciclagem da água e o crescimento das plantas também são alterados pelo PSD. Antes da construção das barragens, os solos depositados nas áreas agrícolas (DF) foram amplamente formados no "Loess Plateau", na China (LPC), onde os mais sérios problemas de erosão do solo ocorreram no mundo. Duas DFs, sem preparo do solo, localizadas no LPC foram escolhidas para estudar conjuntamente o efeito da erosão e das barragens na PSD. Novecentas e trinta e duas amostras de solo foram analisadas usando granulometria a laser, a partir de coletas realizadas em 88 camadas (espessura de $10 \mathrm{~cm}$ cada camada) formadas por deposição de solos em áreas agrícolas (FDF) e em 22 camadas formadas por deposição de silte (SDF). Os tamanhos das partículas foram estratificados, em ambas as DFs, em função das propriedades do solo e de sua resistência à erosão. Os resultados obtidos para as frações silte e argila mostraram que elas possuem distribuição horizontal similar, indicando características paralelas dos processos de erosão e deposição. A areia fina foi a fração mais encontrada, o que sugere uma separação preferencial desta. Das camadas de solo estudadas, a faixa mais erodivel dos tamanhos de partículas foi a de 0,25-0,5 mm, seguida pela de 0,20-0,25 mm. Aumento da correlação entre o tamanho das partículas e o conteúdo de água no solo foi observado na FDF. Devido à abundância de águas subterrâneas superficiais em SDF, os tamanhos de partículas não se relacionaram com o conteúdo de água no solo. Mais estudos sobre a distribuição do tamanho das partículas em DFs são necessários para indicar um melhor manejo e conservação do solo e da água nessas áreas agrícolas.
\end{abstract}

Termos de indexação: textura, estratificação, erodibilidade de solos, construção de barragem, manejo do solo.

\section{INTRODUCTION}

Many countries in the world have been facing catastrophic soil erosion, especially China. The most severe erosion in terms of water, wind, gravitation, and frost is observed on the Loess Plateau of China (CLP) (Kaiser, 2004). Due to the erosion in this region and common particle size transportation, the deposited farmland soils (DFs) were quickly formed upstream of the check dams on the CLP. The DF is not only beneficial to conserve soil as it decreases the energy of runoff and erosion, but it also improves cropland substantially. In this context, the maize yield (Zea mays L.) on DF is reportedly 5-6 times as high as on sloping farmlands and even 10-fold in some areas (Xu \& Wang, 2000). In 2003, $3340 \mathrm{~km}^{2}$ DFs had been formed on the CLP, on which 1.67 billion $\mathrm{kg}$ crop yield per year was produced. Moreover, the area of DFs and crop yield are expected to have doubled by 2020 (Gao \& Zhang, 2007).

On the other hand, information on particle size distribution (PSD) reinforces the important role of DF in agricultural development and soil conservation. PSD throughout the DF is strongly related to the ease of tillage and improvement of capillary conductivity, available moisture, permeability, agricultural development, and to saturated hydraulic conductivity and other soil physical properties (Henderson et al., 2005; Beldini et al., 2009; Tavares et al., 2010). Studies on this topic improve our understanding on what kind of particle size was retained in the DFs as a result of human interventions against soil loss. This information may be required for the establishment of sediment budgets, implementing precision agriculture and estimating the potential of sediment for absorbing and transporting chemicals (Young, 1980; Ampontuah et al., 2006; Amer, 2009). In the case of the Yellow River in China, the main deposition materials raising the river streambed were particles $>0.05 \mathrm{~mm}$, reducing the channel capacity and causing periodic flooding (Tang et al., 1993). However, this range of particle sizes, whether it is well-controlled in the DFs or not, and what kind of other particles also play a role has not been elucidated. In addition, the abundance of a given range of size fractions at a particular location may indicate whether erosion is or its fluctuations are well-controlled or not. Likewise, information about primary particle size transport is necessary to develop improved erosion and sediment models for soil loss predictions (Young, 1980). Ampontuah et al. (2006) warned that the importance 
of assessing soil PSD in agricultural fields or catchments should not be underestimated. Nevertheless, little attention has been paid to the characteristics of particles eroded from the surface of undisturbed soil under natural field condition (Martinez-Mena et al., 1999).

Therefore, the objectives of this study were to investigate and explain the redistribution patterns of various particle size ranges in the profiles of DFs without tillage; assess the range of the most erodible particle size class in this region; and determine the correlation between particle size and soil volumetric water content in the DFs.

\section{MATERIALS AND METHODS}

The study was carried out in the catchment area of Liudaogou of the CLP, which is the center of the region most seriously affected by soil loss in the world (Figure 1). The catchment is controlled and there are no farming activities in the region, due to the steep terrain and the policy banning farming by the Chinese government. Two DFs without tillage (deposition occurred naturally) were selected in this study. One was filled up by sediment (D1) and the other under ongoing deposition (D2). Eighteen sampling points in D1 and D2 were marked equidistantly in the sedimentary direction. The sampling distance intervals were 4 and $3 \mathrm{~m}$ along the sedimentary direction of D1 and D2, respectively. The nearest sample points were both located at a distance of $3 \mathrm{~m}$ from the check dams. Soil samples were taken from the profiles using an auger, from the soil surface to bedrock, at $10 \mathrm{~cm}$ intervals. In this way, 88 and 22 layers were sampled in D1 and D2, respectively. Moreover, 12 soil samples were collected from the surface layer $(0-5 \mathrm{~cm})$ of a sloping area in each controlled catchment. A total of 932 soil samples (648 from D1, 260 from D2 and 24 from sloping area) were air-dried, gently ground with a mortar, sieved (1 mm) and homogenized prior to particle analyses. The samples were dispersed by sodium hexametaphosphate and soil organic matter removed by $30 \% \mathrm{H}_{2} \mathrm{O}_{2}$ in two days.

The particle fractions were determined by laser diffraction, using a Longbench Mastersizer (2000). In the analysis, soil samples were disaggregated with an ultrasonic mixer for $30 \mathrm{~s}$. The measurements were conducted in two replicates. Then the samples were analyzed according to the Chinese taxonomy to characterize PSD; a comparison of the Chinese and international taxonomy is shown in table 1 . The comparison clearly indicated that the Chinese has more classes and porvides more information about PSD in DF than the international taxonomy.

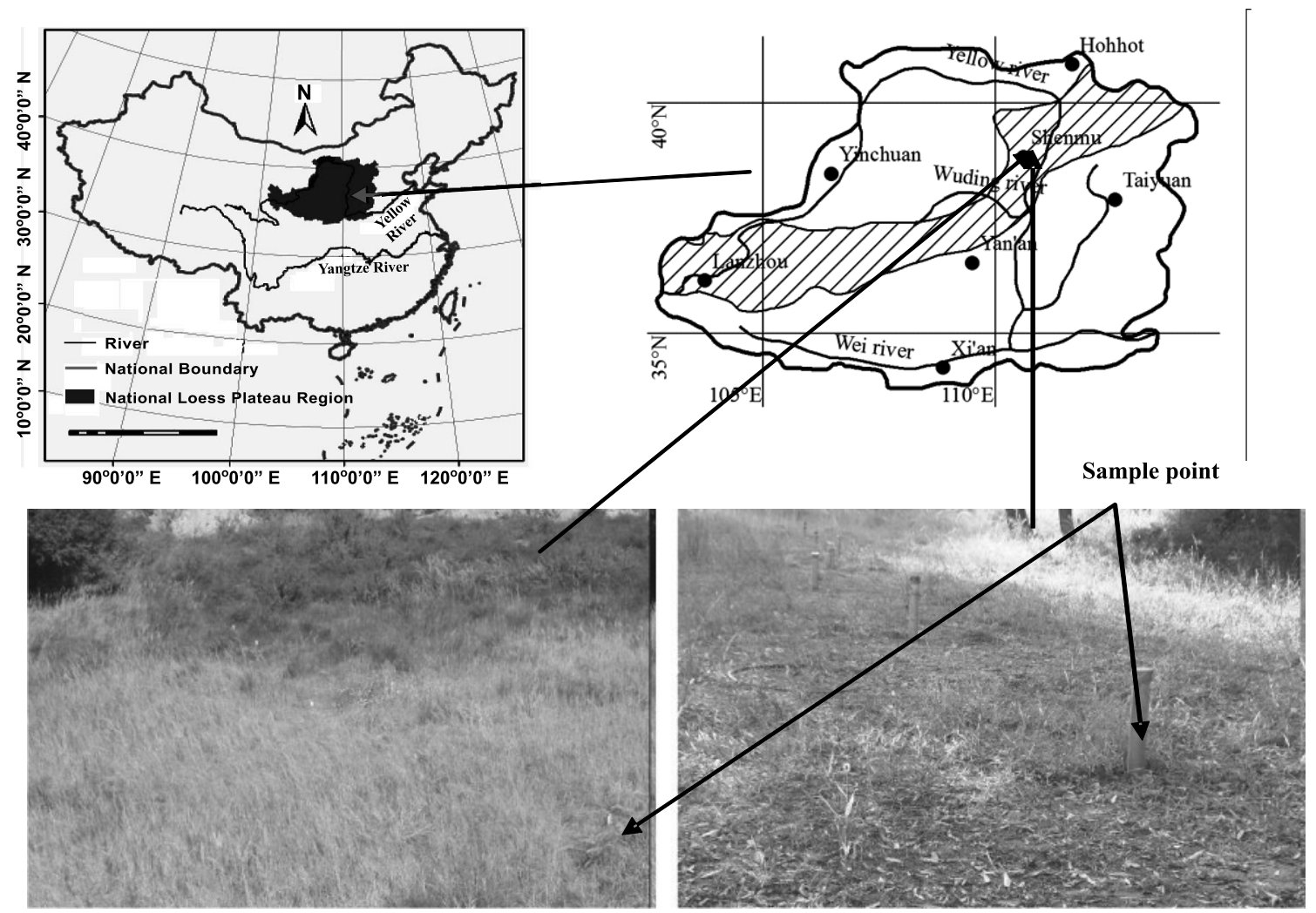

Figure 1. Study location on the Chinese Loess Plateau, with a general view of the deposited farmland soils and sample sites. 
Table 1. Comparison of Chinese taxonomy and international system for particle size

\begin{tabular}{|c|c|c|}
\hline Particle size & $\begin{array}{l}\text { Chinese } \\
\text { system }\end{array}$ & $\begin{array}{c}\text { International } \\
\text { system }\end{array}$ \\
\hline $\mathrm{mm}$ & \multirow{3}{*}{ Gravel } & \multirow{3}{*}{ Gravel } \\
\hline $3-2$ & & \\
\hline $2-1$ & & \\
\hline & \multirow[t]{2}{*}{ Coarse sand } & \multirow[t]{2}{*}{ Coarse sand } \\
\hline $0.25-0.2$ & & \\
\hline $\begin{array}{l}0.2-0.1 \\
0.1-0.05\end{array}$ & Fine sand & \multirow[t]{2}{*}{ Fine sand } \\
\hline $\begin{array}{l}0.05-0.02 \\
0.02-0.01\end{array}$ & Coarse silt & \\
\hline $0.01-0.005$ & Medium silt & Silt \\
\hline $\begin{aligned} & 0.002-0.001 \\
< & 0.001\end{aligned}$ & $\begin{array}{l}\text { Coarse clay } \\
\text { Fine clay }\end{array}$ & Clay \\
\hline
\end{tabular}

\section{RESULTS AND DISCUSSION}

\section{Classic statistical analysis}

The classic statistical properties of particle size in the D1 and D2 profiles are presented in table 2. Obviously, the fine sand fraction, fsa $(0.05-0.25 \mathrm{~mm})$ was the largest fraction and fine clay $(\mathrm{fcl})(<0.001 \mathrm{~mm})$ was the smallest fraction in both $\mathrm{D} 1$ and $\mathrm{D} 2$, according to the Chinese taxonomy.

The coefficient of variation (CV) of coarse sand fraction, csa $(0.5-1 \mathrm{~mm})$ was $103.4 \%$, with a high spatial variability in $\mathrm{D} 1$. However, $\mathrm{CV}$ values ranged from 15.94 to $97.56 \%$ for other particles, indicating a moderate spatial variability at both $\mathrm{DF}$ sites. The two lowest values of CV of both D1 and D2 were associated with the fsa fraction. As indicated by the highest fsa proportion within various particle sizes, this fraction is ubiquitously and homogeneously distributed over the DF profiles. In most studies about particle size distribution, CV was found to range from 10-100 \%, as reported by Hu et al. (2008). The results showed that the effect of erosion and check dams on PSD was significant. From the skewness values, the contents of fcl, coarse clay fraction (ccl), (0.001$0.002 \mathrm{~mm}$ ), the fine silt (fsi) $(0.002-0.005 \mathrm{~mm}$ ), and medium silt fractions (msi) $(0.005-0.01 \mathrm{~mm})$ showed right-tailed distribution tending to low values on the profiles, including the coarse silt fraction (csi) (0.01$0.05 \mathrm{~mm}$ ) of D2. Likewise, the contents of fsa and sand fraction (sa) (0.05-1 $\mathrm{mm}$ ) in D1, with symmetric data for the skewness coefficient, were close to 0 , including the csa of D2. However, the data of fsa and sa in D2 showed a left-tailed distribution tending to high values.

The mean proportion of sa was $65.82 \%$ in D1 and 69.09 \% in D2, respectively. Tang et al. (1993) stated that the deposition of the sa fraction was the main reason for the rise of the Yellow River bed. Concerning the low values of $\mathrm{CV}$, the data generally indicate good ability of DFs in controlling the main materials threatening the safety of the Yellow River.

\section{Particle redistribution on the profiles}

The spatial redistributions of various particle sizes in the D1 profile are presented in figure 2. Obviously, horizontal distributions of fcl and ccl are seen on the profiles. However, the horizontal distributions are not consecutive or equidistant. The intermittent distribution was due to the different rainfall intensity and runoff amount. Severe rainfall and runoff always carry the particles far away and form long and thick stratification structures. The fsi and msi, with high proportions, have similar distribution trends as the clay fraction $(\mathrm{cl}<0.002 \mathrm{~mm})$.

The proportion of csi was high, appearing frequently and clearly in horizontal distribution. In general, the distribution trend of the $\mathrm{cl}$ and silt fractions (si $0.002-0.05 \mathrm{~mm}$ ) was similar in the D1 profiles. This result indicated similar detachment and deposition characteristics of $\mathrm{cl}$ and si in the soil erosion processes. The patterns in D1 reflected the highest concentrations of cl and si fractions, deposited mainly on the topsoil, on the right side of the DF. This phenomenon occurred since the fine particles were carried farther away in the deposition process. The distribution of $\mathrm{cl}$ and si also had several significant environmental and economic implications. For example, fine particles

Table 2. Classical statistics of the particle size on the two profiles of deposited farmland soils

\begin{tabular}{|c|c|c|c|c|c|c|c|c|}
\hline \multirow{2}{*}{ Particle size } & \multicolumn{2}{|c|}{ Mean } & \multicolumn{2}{|c|}{ Variance } & \multicolumn{2}{|c|}{ CV } & \multicolumn{2}{|c|}{ Skewness } \\
\hline & D1 & D2 & D1 & $\overline{\text { D2 }}$ & D1 & D2 & D1 & $\overline{\mathrm{D} 2}$ \\
\hline $\mathrm{mm}$ & & & & & 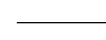 & & & \\
\hline$<0.001$ & $1.07 \pm 0.04$ & $1.09 \pm 0.08$ & 0.85 & 1.11 & 86.17 & 97.49 & 6.06 & 4.20 \\
\hline $0.001-0.002$ & $1.27 \pm 0.03$ & $1.35 \pm 0.10$ & 0.43 & 1.74 & 53.13 & 97.56 & 4.67 & 4.21 \\
\hline $0.002-0.005$ & $3.38 \pm 0.05$ & $3.41 \pm 0.14$ & 1.15 & 3.38 & 31.74 & 53.97 & 2.89 & 3.48 \\
\hline $0.005-0.01$ & $3.94 \pm 0.06$ & $3.77 \pm 0.17$ & 1.60 & 4.88 & 32.13 & 58.52 & 2.15 & 3.26 \\
\hline $0.01-0.05$ & $24.52 \pm 0.38$ & $21.23 \pm 0.67$ & 66.07 & 76.51 & 33.15 & 41.20 & 0.57 & 2.02 \\
\hline $0.05-0.25$ & $56.53 \pm 0.42$ & $58.44 \pm 0.94$ & 81.23 & 150.35 & 15.94 & 20.98 & -0.87 & -2.43 \\
\hline $0.25-1$ & $9.29 \pm 0.44$ & $10.71 \pm 0.45$ & 92.26 & 34.62 & 103.40 & 54.92 & 1.51 & 0.43 \\
\hline $0.05-1$ & $65.82 \pm 0.45$ & $69.09 \pm 1.11$ & 123.55 & 209.64 & 16.89 & 20.96 & -0.93 & -2.54 \\
\hline
\end{tabular}

$\mathrm{D} 1$, filled deposited farmland soil; D2, silting deposited farmland soil; CV, coefficient of variation. 


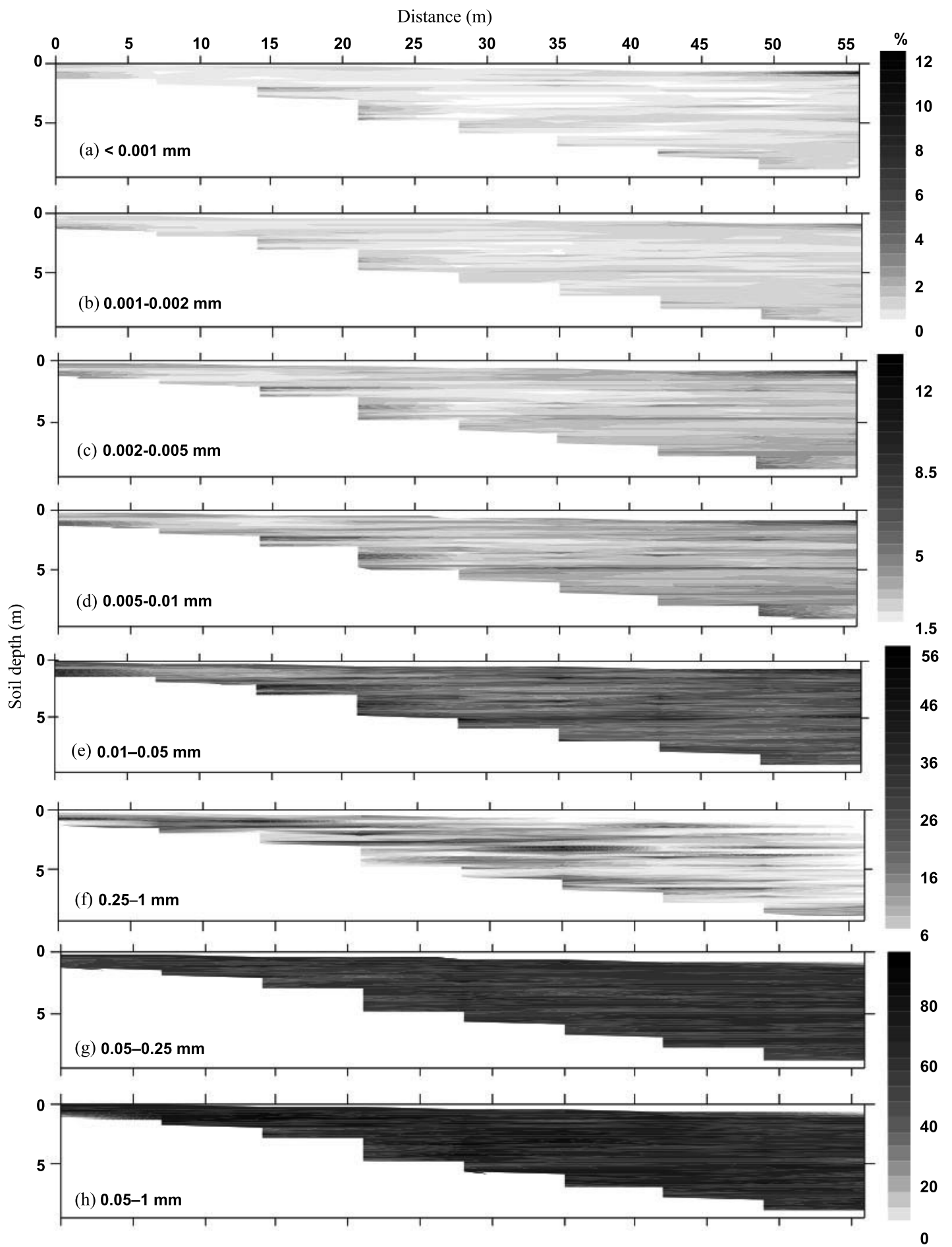

Figure 2. The redistributions of various particle sizes within Chinese taxonomy on the profile of filled deposited farmland soil (the direction of erosion flow is from 0 to 55).

(cl and si) were greatly enriched with nutrients and organic matter, which has a strong influence on the soil water-holding capacity and fertility. Consequently, the information on particle size distribution was helpful in the development of precision agriculture for the DFs. For example, crops with greater nutrient and water requirement could be planted on areas where fine particles are accumulated.
The dominant fraction in D1 is fsa. The horizontal distribution of these particles was also observed along the profile, but finer particles were predominant. However, the stratification trend was vague in view of the high proportion and low variability in the profile. For the csa, the lower proportion clarified the stratification again. This kind of particles was mainly found in the deep soil layers and rarely on the slope, 
especially on the surface soil on the right side. This phenomenon was also strongly related to the deposition process, where coarse particles are deposited first and then fine particles, which were transported farther. A high sa content was distributed along the $\mathrm{D} 1$ profiles. Obviously, a relatively higher sa proportion was deposited on the left side and in the middle part of D1. In the dataset, the sample with the highest sa content (i.e. $87.61 \%$ ) was found at the deposition source. This was also related to the deposition rule of different particles in a redistribution process. In D2, the spatial patterns of various particles in the different profiles were similar to D1 (shown in Figure 3). Due to the short deposition period and thin deposition layer in D2, the stratification structure did not appear as frequently as in D1. However, sa becomes more predominant, as shown in table 1 and figure 3 . In general, the spatial patterns of various particle sizes in the DFs were mainly related to the deposition characteristics of particles. In the runoff process, the

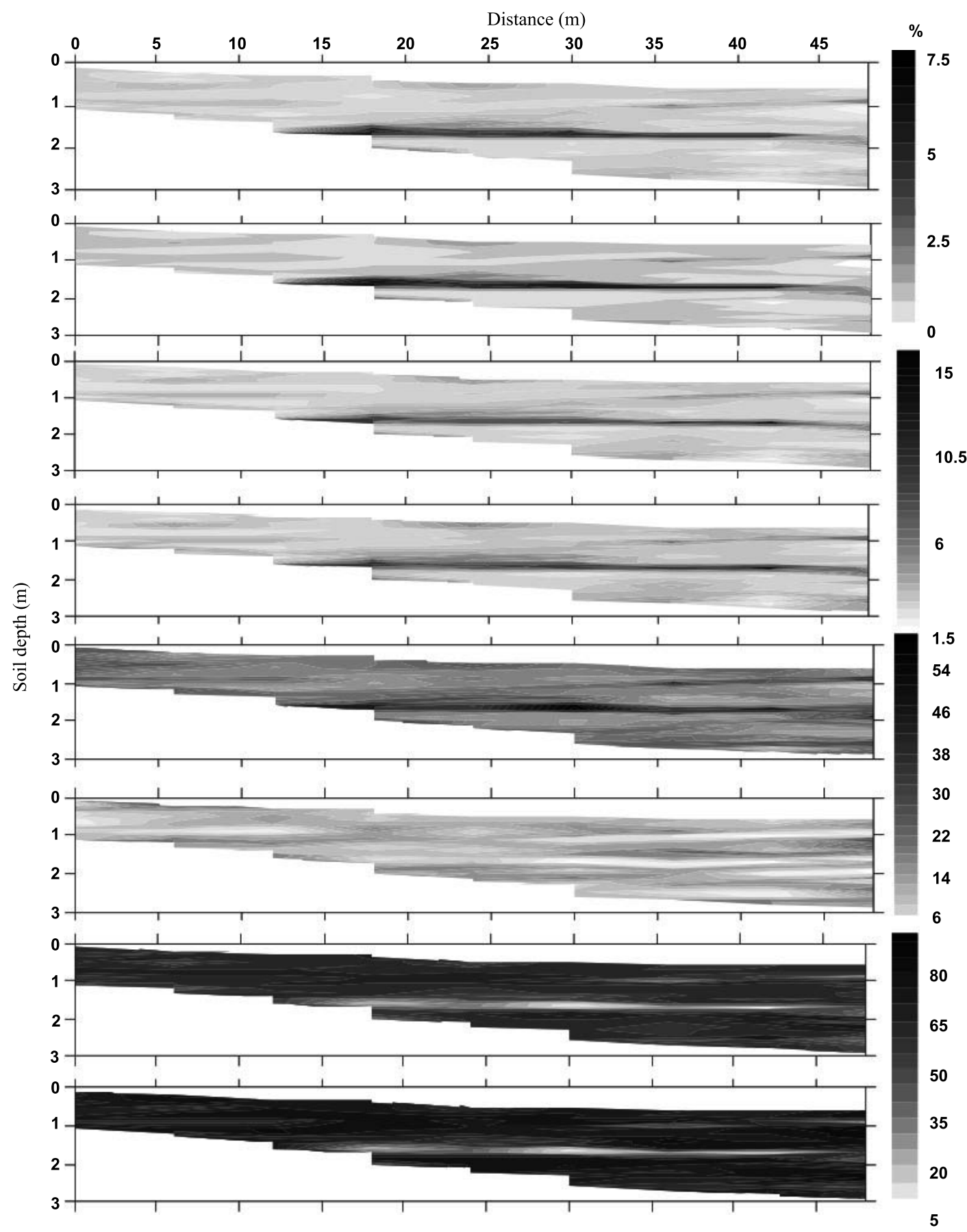

Figure 3. The redistributions of various particle sizes within Chinese taxonomy on the profile of silting deposited farmland soil (the direction of erosion flow is from 0 to 45 ). 
particles covered the former topsoil with different amount and particle sizes, over and over again. Consequently, particle stratification was clearly existent in the DF profiles since the particles were deposited at different times.

The horizontal distribution of particle sizes controlled the appearance of the soil layers. The occurrence of preferential flow, which may transport chemicals or contaminant materials into the groundwater quickly, was mainly influenced by the layered soils of the DF (Zhao et al., 2010). The finding of stratification in the DFs agreed with the results of Boll et al. (1996), who found the layered structure in fluvial deposition by radar. Also, the study of Zhao \& Shao (2010) explores the stratification of particles by the relationship between particles and soil water content in the DF.

\section{Enrichment ratio of particles}

To identify the most erodible particle-size group in this region, the enrichment ratio (ER) of various particles in the two DFs was compared (Figure 4). In this study, the ER value was calculated by the mean proportion of various particles in the $\mathrm{DF}$, by dividing the proportions of particles collected from controlled sloping areas. For a more specific range, a more detailed classification than the Chinese taxonomy was applied (see x-axes of Figure 4). In D1, the range of $0.25-0.5 \mathrm{~mm}$ fraction of the sediment has the highest ER of 2.78 followed by the $0.2-0.25 \mathrm{~mm}$ fraction with an ER of 2.12. The same result was found in D2. This means that the $0.25-0.5 \mathrm{~mm}$ particle range was the most erodible in this region. This result contradicted the study of Young (1980), who found that $0.02-0.2 \mathrm{~mm}$ was the most erodible particle-size group. This can be explained by the fact that soil erosion and soil loss were mainly associated with heavy rains on the CLP, and the eroded soil was sandy loam with high sa contents, as explained by Hu et al. (2008). Consequently, the various eroded environments and materials, and mainly rainfall intensity and soil texture, would determine the most erodible particlesize group. Moreover, the ER of the particles $>0.05 \mathrm{~mm}$ was $>1$. This implies that these fractions were easily detached in the soil erosion process.

Soils with very high sa are not well-aggregated and thus tend to erode before the other particles. The ER values of the particles that belong to cl or si are always $<1$. The results illustrated that the fine particles (i.e. cl and si) are resistant to the soil erosion process due to their aggregate structure. However, Ampontuah et al. (2006) were concerned that the high silt content could lead to high soil erosion. From the results of this research, the characteristics of the high silt content were relatively stable with regard to the water erosion on the CLP. For the fraction 0.5-1 mm, greater strength is required to transport these particles because of the greater gravitation. As a consequence, this range has a lower ER than the fractions of 0.25$0.5 \mathrm{~mm}$ and $0.2-0.25 \mathrm{~mm}$, and was more stable.

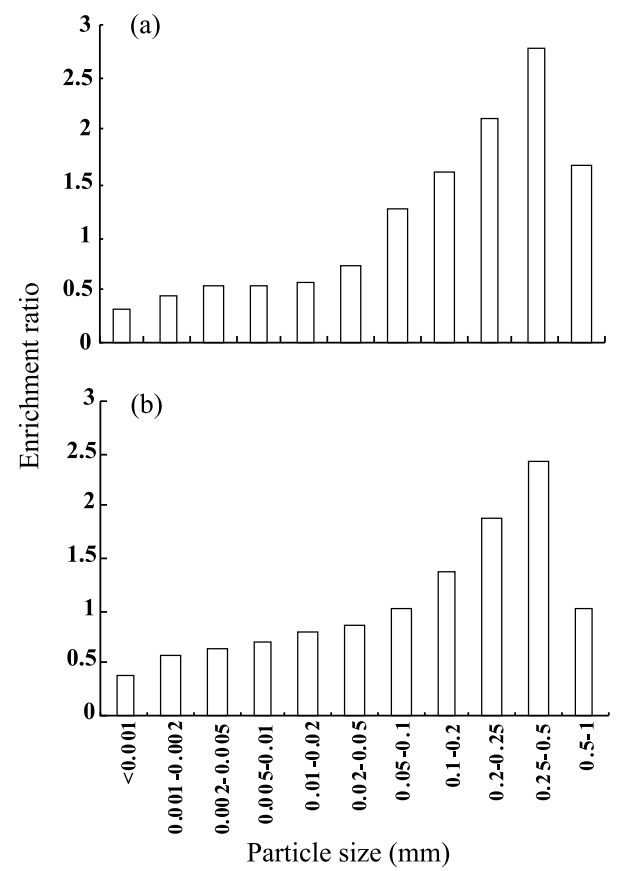

Figure 4. The enrichment ratio of various particlesize groups in detailed classes in the two deposited farmland soils; (a) filled deposited farmland soil; (b) silting deposited farmland soil.

Wang et al. (2008) reported that the DF soils had higher soil organic $\mathrm{C}$ contents than the sloping land soils. As it is well-known, the content of soil organic $\mathrm{C}$ has a positive linear relationship with the value of fine particles (e.g. cl fraction, Quiroga, 1996). Despite the higher sand fraction, more carbon was captured in the DF than in sloping areas under no tillage. Consequently, the DF on the CLP contribute greatly to carbon sequestration, due to the large scope and long time of this soil conservation practice.

\section{Correlation analysis between soil water content and particle-size groups}

The particle size has a great effect on soil water distribution and movement (Zhao et al., 2010). The relationship between the particles and the volumetric soil water content was analyzed by SPSS 16.0 (SPSS, 2007). The soil water contents were assessed on different dates by a neutron probe to represent wet and dry conditions (Zhao et al., 2010). Table 3 shows Pearson's correlation coefficients between soil water content and various particles of $\mathrm{D} 1$ for several random days.

All particles size groups were significantly related with soil water content. The cl and si fractions were significantly related with the soil water content at the $1 \%$ significance level. To detect the effect of changed water content on the relationship between soil water and particle sizes, the Pearson's coefficient and the mean soil water content of D1 were linearly fitted (Figure 5), as foreseen in the Chinese taxonomy. 
Table 3. Pearson correlation coefficients between the particles and soil water content in the filled deposited farmland soils of random days as a sample

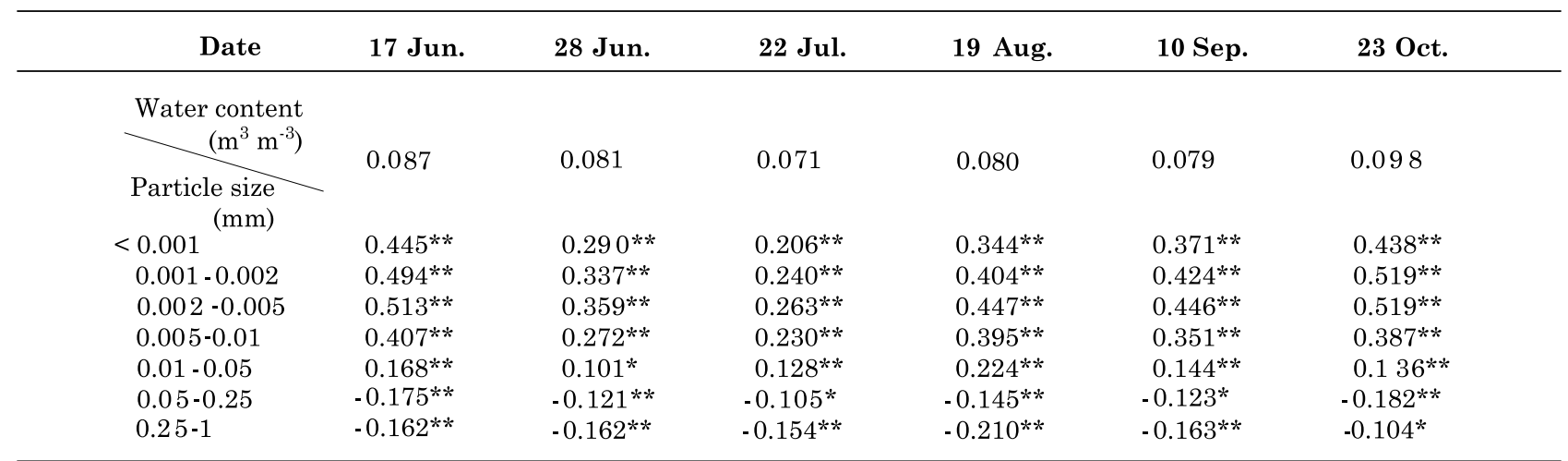

**: correlation significant at the 0.01 level (2-tailed). *: correlation significant at the 0.05 level (2-tailed).
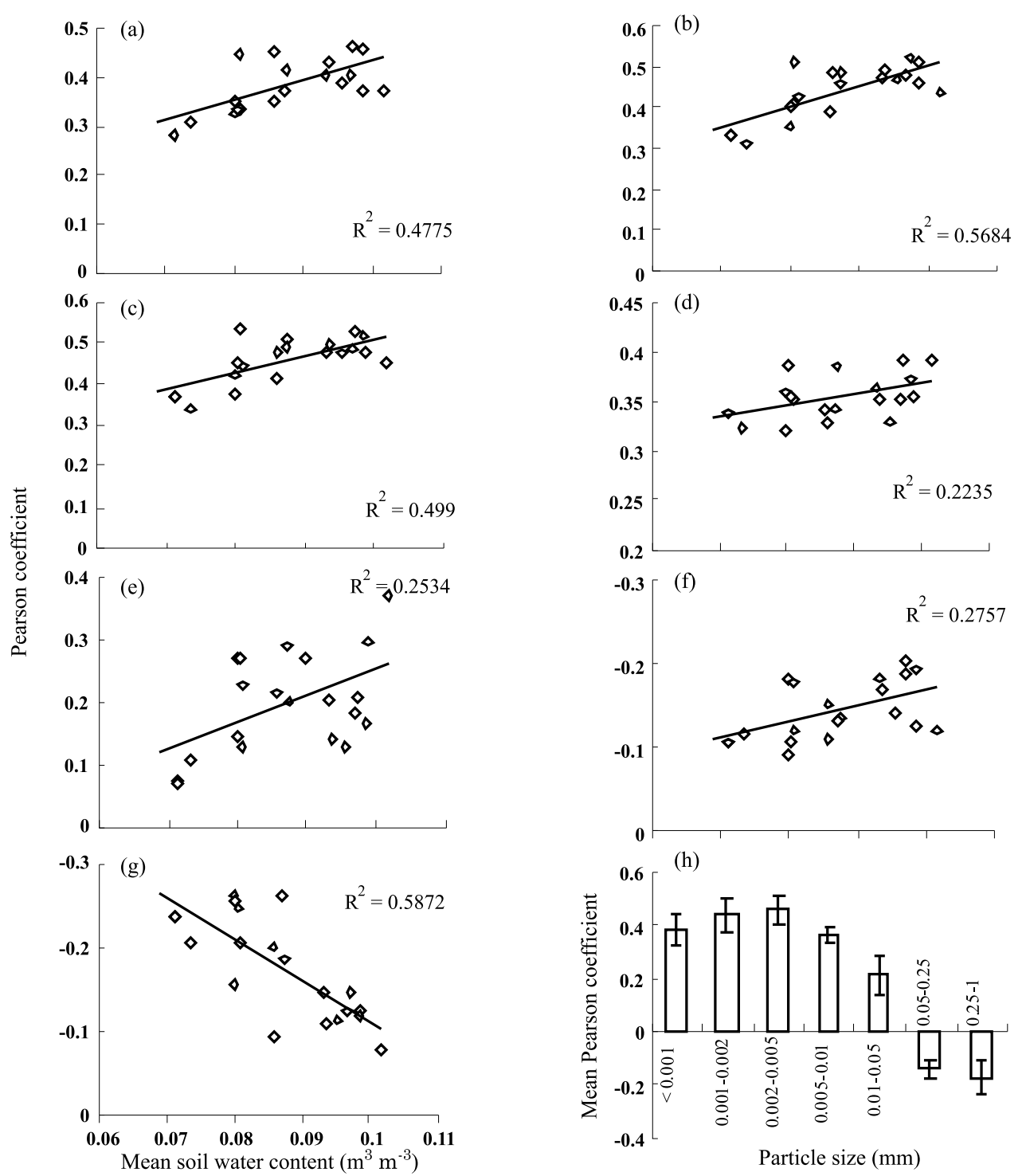

Figure 5. The linear fitting between mean soil water content and Pearson coefficient for particle sizes in the filled deposited farmland soil; (a) <0.001mm; (b) 0.001-0.002 mm; (c) 0.002-0.005; (d) 0.005-0.01 mm; (e) 0.01-0.05 mm; (f) 0.05-25 mm; (g) 0.25-1 mm; (h) the mean values of Pearson coefficient. 
Figure 5 shows that the correlation between the particle-size group and mean soil water content becomes more relevant as the soil water increases $(p<0.05)$, with exception of csa. Due to the large pore structure, the low soil water content is more significantly related with cas in the DF. Hu et al. (2008) observed no correlations with particle size at low soil water contents. This result indicates the trend of most particle size groups to show low correction with the soil water content, except for the csa fraction, which tends to be more prevalent with soil water content in the DF. The range of $0.002-0.005 \mathrm{~mm}$ has the most significant effect on the soil water content in D1, followed by 0.001-0.002 mm (Figure $5 \mathrm{~h}$ ). Generally, disregarding their significance level, cl and si were positively and sa negatively correlated with soil water content. However, no relationship was found between particle-size group and soil water content for D2 in this study. This could be explained by deposition effects, leading to the retention of great amounts of shallow groundwater by the dam body, as well as to the presence of air and water in the pores. This air affects the relationship between particles and soil water content negatively.

\section{CONCLUSIONS}

1. This study reported a layered structure of various particle-size groups in the profiles of deposited farmland soil. The distribution patterns of the particles were the basis of soil layers that strongly influence water distribution and movement.

2. This study reported an increased erodibility of soils with high sand fractions and low clay and silt contents. In this research, the particle size range of 0.25-0.5 mm was the most susceptible to soil erosion.

3 . The range of erodible particles differed according to the different eroded material and environmental conditions. Particles of $0.002-0.005 \mathrm{~mm}$ were most strongly related with soil water content in the sediment of filled deposited farmland soil. With increasing soil water content, a significant correlation between particles and increased soil water was found, except for the coarse sand fraction, with an opposite trend.

\section{ACKNOWLEDGEMENTS}

This study was supported by the Fund of Chinese Academy of Sciences Dean's Excellent Award and Process simulation of soil and water of a watershed and the Program for Innovative Research Team in University (No. IRT0749). We express our most sincere thanks to the reviewers and editors for their important contributions to this paper. We thank Dr. L. Timm sincerely for his help on portuguese abstract.

\section{LITERATURE CITED}

AMPONTUAH, E.O.; ROBINSON, J.S. \& NORTCLIFF, S. Assessment of soil particle redistribution on two contrasting cultivated hillslopes. Geoderma, 132:324-343, 2006.

AMER, A. Moisture adsorption capacity and surface area as deduced from vapour pressure isotherms in relation to hygroscopic water of soils. Biologia, 64:516-521, 2009.

BELDINI, T.P.; MCNABB, K.L.; LOCKABY, B.G.; SANCHEZ, F.; NAVEGANTES-CÂNCIO, O. \& OLIVEIRA, R. The effect of plantation silviculture on soil organic matter and particle-size fractions in Amazonia. R. Bras. Ci. Solo, 33:1593-1602, 2009.

BOLL, J.; VAN-RIJN, R.P.G. \& WEILER, K.W. Using ground penetrating radar to detect layers in a sandy field soil. Geoderma, 70:117-132, 1996.

GAO, Z.L. \& ZHANG, X.P. Study on the construction and layout of check-dams on the Loess Plateau. Beijing, The Central Committee Documents Publishing House, 2007.

HENDERSON, J.J.; CRUM, J.R. \& WOLFF, T.F. Effects of particle size distribution and water content at compaction on saturated hydraulic conductivity and strength of high sand content root zone materials. Soil Sci., 170:315-324, 2005.

HU, W.; SHAO, M.; WANG, Q. \& REICHARDT, K. Soil water content temporal-spatial variability of the surface layers of a Loess Plateau hillside in China. Sci. Agric., 65:277289,2008

KAISER, J. Wounding earth's fragile skin. Science, 304:16161618, 2004.

MARTINEZ-MENA, M.; ALVAREZ, R. J. \& ALBALADEJO, J.V. Influence of vegetal cover on sediment particle size distribution in natural rainfall conditions in a semiarid environment. Catena, 38:175-190, 1999.

QUIROGA, A. Soil organic matter particle size fractions in soils of the semiarid Argentinian Pampas. Soil Sci., 161:104-108, 1996.

SPSS. SPSS Version 16.0 for Windows. Chicago, 2007.

TANG, K.L.; HOU, Q.C. \& WANG, B.K. The environment background and administration way of Wind-Water Erosion Crisscross Region and Shenmu experimental area on the Loess Plateau. Memoir of NISWC. Academia Sinica MWR, 18:2-15, 1993.

TAVARES, F.J.; BARBOSA, G. \& RIBON, A. Physical properties of dystrophic Red Latosol (Oxisol) under different agricultural uses. R. Bras. Ci. Solo, 34:925-933, 2010.

WANG, Y.; ZHANG, X. \& HANG, F. Profile variability of soil properties in check dam on the loess plateau and its functions. Environ. Sci., 29:1020-1027, 2008.

XU, M. \& WANG, G. To accelerate the construction of checkdams in the Loess Plateau. Yellow River, 22:26, 2000. 
YOUNG, R.A. Characteristics of eroded sediment. Trans. ASAE., 23:1139-1142, 1146, 1980

ZHAO, P. \& SHAO, M. Soil water spatial distribution in dam farmland on the Loess Plateau, China. Acta Agr. Scand. Sect. B - Soil Plant, 60:117-125, 2010.
ZHAO, P.; SHAO, M. \& MELEGY, A. Soil water distribution and movement in layered soils of a dam farmland. Water Res. Manag., 24:3871-3883, 2010. 